\title{
Egge Kulbok-Lattik
}

\section{THE HISTORICAL FORMATION AND DEVELOPMENT OF ESTONIAN CULTURAL POLICY:TRACING THE DEVELOPMENT OF ESTONIAN COMMUNITY HOUSES (RAHVAMAJA)}

\begin{abstract}
MA Egge Kulbok-Lattikin kulttuuri- ja yhteiskuntapolitiikan väitöskirjatyön "The Historical Formation and Development of Estonian Cultural Policy: Tracing the Development of Estonian Community Houses (Rahvamaja)" tarkastustilaisuus pidettiiin 17.10.2015 Jyväskylän yliopistossa. Vastaväittäjänä toimi professori Mikko Lagerspetz (Åbo Akademi) ja kustoksena professori Anita Kangas (Jyväskylän yliopisto).
\end{abstract}

When Tom Stoppard visited the Tallinn literary festival in May 2013, during one of the public discussions, he asked: How might it be explained that during Soviet times everybody had access to high culture? His partner in this discussion, Estonian president Toomas Hendrik Ilves, as a representive of that part of Estonian nation who had to leave their homes in order to escape from the totalitarian regime, could not really answer the question. Neither could anybody from the audience offer a good explanation to this, the cultural aspect of Soviet welfare.

It is because until recent times there has not been a proper discussion on the issue of what the cultural program of civilizing the masses of Soviet state was. Was the culture just a propaganda tool, as it has been frequently seen? What did it take from us, and what did it gave to us - to those generations who were born and became adults as 'cultured Soviet persons' in the 'cultural welfare' of a closed society? Where did the cultural power come from during the days of perestroika and the Singing Revolution?

My dissertation The Historical Formation and Development of Estonian Cultural Policy: Tracing the Development of Estonian Community Houses (Rahvamaja) discusses these matters and aims to reflect on the historical experience of Estonian politics of culture. Dissertation is based on peer-reviewed articles and belongs to the field of historical sociology.

I have been interested in discovering the roots of the cultural policy of the Estonian state and its developments during the first period of Estonian Republic (1918-40), as well as during the period of Soviet occupation (1940-91). My aim has been to identify historical patterns and developmental processes of Estonian cultural policy as modern state practice, also to analyze relations between civil society and state during various socio-economic and political systems. Looking at how social structures are shaped by complex social processes and how the structures in turn shape institutions and organizations, and they affect the society and individuals, (Tilly 1980, 55-59), has been my interest. And contemporary historical sociology is primarily concerned with how the state has developed, analyzing relations between classes, economic and political systems.

It was my personal background that prompted me to research cultural policy, and thus, desire to understand and explain the historical processes as well as the connections between 
economy, culture and politics, has led me to examine the Estonian cultural policy with methods from historical sociology, which is a branch of sociology focusing on how societies develop through history.

To understand the connections and interactions between civil society and modern state during different political eras of Estonian history, I have chosen as a case study the historical emergence and development of Estonian community ${ }^{1}$ houses (rahvamaja). Estonian community houses hosted cultural and leisure activities of the local population and were built in towns and the countryside by people who joined societies since the second half of the nineteenth century. These houses became pre-state cultural institutions, which supported the development of Estonian cultural identity, the process of nation building and the public sphere. This process of bottom-up initiatives and shared cultural practices illustrates the constitution of Estonian civil society.

The notion of civil society as a concept in academic discourse as well as in practical phenomena depends on the political system in the relevant society. It refers to different activities contrasted with the state but not reducible to the market, being located somewhere in between. Civil society acts as a social sphere which helps redistribute power in society, providing people with opportunities to take part in the political decision-making process, with decisions being made on different levels, being divided between smaller processes (participatory practices, subpolices), instead of in one power centre.

With the example of community houses, the historical roots, formation, aims, and development of Estonian cultural policy can be observed.

Thus, I have been looking for answers to the following research questions:

- What are the specific features of the historical development of Estonian cultural policy?

- How was the Soviet cultural policy implemented in Estonia in the years 194091 ?

- What was the role of community houses in the development of Estonian national culture and public sphere during the different political systems ${ }^{2}$ between 1880 and 1991?

In order to identify the connections between historical processes, I have used historical analysis and historical periodization as methods with a focus on the development of Estonian cultural policy. Explaining the formation of historical process, I rely on the ideas of Yuri Lotman (1999, 125-137), who places the historical process in his model of cultural dynamics, according to which the formation of historical process is shaped in the tensions and interactions by long and continuous general processes (that might remain invisible to individuals), and by the efforts - spiritual or based on the will - of individuals.

A periodization of historical processes is one way of reconstructing the past. Epistemologically, periodization is justified by the natural human need for clarity: we need to find clear boundaries in the collection of facts and events that history deals with. Of course, periodization is always a subjective and conditional method, and can lead to both a dangerous over-simplification. Despite this, I suggest that it allows a broader generalisation and an overview when discussing, for instance, such a complex topic as the history of Estonian cultural policy. I have used periodization as method in the first article, 'On the Historical Periodisation of Estonian Cultural Policy', also, the organisational and economic layout of cultural production during different political systems (in the summary text and in the second and the third articles) has been identified in the dissertation.

Another method used in this dissertation is the sociological case study on Estonian community houses as institutional agent but also an instrument of cultural policy. A case study as an organizing principle is holistic and exhaustive, and what Geertz, (1973) called of 'thick description', which is essential in order to understand context and situation.

The case study on Estonian community houses is presented in two articles in the dissertation: in the first, the historical preconditions for the emergence of society and community houses, are examined, as well as the roots and 
development of cultural policy of the Estonian nation state (1918-1940) is reflected. And in the second, the implementation of Soviet cultural policy model between 1940 and 1991, within the process of Sovietization has been examined.

The data I have used contains secondary sources - previous research in related disciplines, as well as primary sources and empirical data - archival documents. I examined and analysed more than 100 archival documents, printed texts and brochures as primary sources: reports, official documents, decrees, regulations, printed orders, laws, methodical guidelines, thematic brochures and recommended repertoires and all kinds of different educational booklets provided by these institutions during the different eras from 1940 to 1973.

In sum, the following thesis is an interdisciplinary analysis of the history of Estonian politics of culture and belongs to the field of historical sociology. Thick description and process analysis enables an understanding of the context of cultural policy and the Estonian-specific historical experience of the state practices in culture during different political systems. The focus on cultural policy gives additional analytical perspective on the past and present in the critical reflection of Estonian society. Further, the concepts and theories of contemporary cultural policy studies and social sciences, which have been used in this dissertation, underpin further participation in international academic discussions, and help reflect on Estonian historical experience in cultural policy comparatively with other European societies.

\section{$* * *$}

The concept of cultural policy is conceptualized in two ways: in a broad sense, cultural policy deals with the clash of interests, the history of ideas, institutional struggles and power relations and the circulation of symbolic meaning in society, as McGuigan $(1996,1)$ notes. In a limited perspective, cultural policies are seen as tools for the administration of the arts, the cultural practices of the general population and researched as one of the public policies of the modern state.
The roots of the concept of cultural policy as a modern state practice lie in the emergence of post-Enlightenment nation states, when culture interpreted in terms of the arts became linked to the administrative apparatus of the state. The state, with its institutions, has the ability to guarantee the development of education and national culture as an aspect of identity politics which form the basis for the legitimation of the state as an institution of governance. In these connections also lie other civilizing aims of the state politics of culture: education, cultivation, based on the ideals of Enlightenment or (Bildung) as well as state custody of the arts - shaping the cultural canon, which is imposed by inclusion and exclusion mechanisms of state support and financial aid to the different cultural practices.

In respect of different cultural practices fields of aesthetics and forms of arts, decisions of exclusion or inclusion are determined by a specific historical outline of a system of values, structure of feelings and social order, the orientation of which is specific to each country. Thus, the differences in the specific historical conditions which shape the selective tradition are keys in considering the differences in the historical development of cultural policies as state policies.

While speaking about cultural policy as public policy, the concept of public policy is rooted in the modernizing political administrative culture and institutions of the 'Western' 'Rechtsstaat', but further, it appeals to both: a general quest for control (Van Gunsteren, 1976) and a psychological desire for a rational order of things'. Thus, the cultural policy as public policy for the arts was seen as a tool to handle the 'anarchy' of unregulated developments in culture, and politics was the major stimulus to 'enlightened' state intervention, as McGuigan (2004, 35) notes. He explains this with 'the idea that the modern nation-state should command the whole of society, regulate the economy and cultivate appropriate selves'. (ibid.)

This desire for a 'rational order of things' was the characteristic and prevailing ethos in all European countries with the process of Western (and also Eastern, Soviet) modernization. 
The concept of public policy has two general notions: first, that governmental actions (or inaction) constitute value choices, that these choices are policies, and that the policies are politically determined; second, that the decisions of public administration (governmental apparatus, legislation, funding, bureaucracy) are implemented by the production of goods and services that produce discernable societal outcomes, or rather that those activities have influence on the lives of citizens.

However, cultural policy as public policy differs substantially from other public policies, as Mulcahy $(2006,320)$ and Bennet (2004) have pointed out, and its' outcome as well as societal impact is difficult to assess. Because the influence of cultural policy is wide-ranging and Foucault's (1991 [1978]) concept of discipline and governmentality helps to explain the interaction of cultural policy as public policy, and social order in society, as well as the historical set of people's differing cultural practices.

Foucault's concept of governmentality refers in a very general way to the administrative powers of modernity - concentrating on the disciplinary regulatory apparatus of the state, but also on the economy and civil society - 'each of which has its power relations, disciplinary technologies, and modes of functioning. Analyzing the various disciplinary institutions, like the police, clinics and prisons, Foucault shows that administrative control enables a modern state to become a coordinating centre of the disciplinary power which intervenes in a societal domain, structures the social regulation and thus, affects the social order.

However, according to Foucault, power based on social order is a much broader than power stemming from the disciplinary technologies, including explicit cultural policy of a modern state, this first and foremost because 'culture' is restricted to practices that social order has provided with different meanings. Foucault $(1991,194)$ handles power as a mechanism, a network, which interacts not only from top to bottom but also vice versa. Although the pyramidal structure of power has its clearly defined 'head', the institutional apparatus as a whole produces power. This enables the disciplinary power to be both direct and indirect: direct, as it is everywhere at the same time; indirect because this power interacts constantly and mostly silently and inconspicuously.

According to Foucault's power theory, in order to be able to dominate, power has to create reality through 'the rituals of truth'. In this process, the individual obeys power not because of threats but because of discipline. Foucault (ibid., 2005, [1971]) states that with the help of discipline - through supervision, control, distinguishing, hierarchiazation, homogenisation, elimination, in short through standardisation an individual is created. Thus, Foucault's ideas indicate national cultural policy as one of the central instruments of power of the ruling ideology, identity and memory-work in society.

$$
* * *
$$

Concerning the specific features of the historical development of Estonian cultural policy - I found out, that the roots of Estonian cultural policy, as well as the origin of cultural institutions lie in the bottom-up initiatives of civil society activities with civilizing aims (Bildung) in order to support cultural and national development.

Estonian cultural aspirations (since the 1860s), were driven by nineteenth century economic, social and political modernization, which formed the preconditions for the emergence of civil society and cultural emancipation. As a result of Russian absolutist central power and the socio-economic situation dominated by the Baltic German nobility, the elite of the 'awakened peasants' was highly motivated to build up their cultural and public sphere with the intention of improving the status of Estonians in society, as many historians have pointed out. Estonian national aspirations (which initially were connected with cultural goals) with time became more political, demanding 'equal rights' compared to the ruling Baltic-German nobility with regard to participation in the running of local affairs.

In this dissertation, open discussions in newspapers, political debates and activities among the Estonian elite who guided the polit- 
ical and social movements are theorised using the Habermasian idea of public sphere. Bottom-up cultural activities - including the building of society and community houses which became the first cultural institutions and public fora for civil society without explicit political aims - are theorised using Bakhtin's public square in this dissertation.

These two parallel cultural movements, as part of civil society, intertwined and formed wider public sphere, and thus, contributed to the formation of a successful Estonian nationbuilding movement. The movement started with cultural practices and a shared feeling of togetherness, reinforcing the basis for national identity and thus supported the process of state-building by bringing the ideas of the Estonian elite to the grass-roots level (1860-1918), resulted in political self-determination. It could be said, that to become cultured, was highly political matter for Estonians.

However, political mobilization connected inherently with cultural emancipation is not the specific feature of the Estonian experience, as this kind of developmental path has been a typical process of modernization also of the many other nations with a colonial past in Europe, as Hroch (1996) has shown.

\section{$* * *$}

\section{Discussing the main aims of the politics of} culture of the modern Estonian nation-state (1918-40), a civilizing, nationalist programme and the institutionalization of the cultural field in order to support national identity and cultural development, could be pointed out. Similar aims appeared to be the central in the cultural policies of nation-states at the beginning of twentieth century, all over Europe.

However, as it appears here, despite the similar aims, state practices and the ways in which cultural policy was implemented differ in various political systems and are always determined by the prevailing political discourse. And that is where the specific feature in cultural politics of Estonia and other Baltic countries appear.

The specific feature is Estonian historical experience within the different state practices in culture during various political systems, conceptualized as 'multiple modernities'. The concept of 'multiple modernities' acknowledges divergent trajectories of development in the modern era and offers a theoretical umbrella under which to discuss, compare and contrast the different macro-historical paths of Western and Eastern Europe (Wittrock 2000, Arnason 2000, Eisenstadt 2000). ${ }^{4}$

Thus, in the pattern of Western modernity we can follow the Estonian nation-building process as hidden resistance, cultural emancipation and the emerging public sphere as inherently cultural political process which started from the bottom-up activities of civil society in the circumstances of the repressive Tsarist Empire during the years 1860-1918. We can follow the rise and development of nations-state with liberal and industrial capitalism of (1918-30s) and democratic practices in cultural policy. In this pattern the dialogue and practical cooperation between the state and the civil society was vital in culture (and in all other spheres of life). Civil society with its' entrepreneurial spirit was broadly involved in civilizing and inculcation activities, while a well-developed state network of cultural institutions was also established in Estonia.

From 1934-40, the practices of the authoritarian state with a cultural policy aimed at creating homogeneous Estonian nation followed, but this variety of state practices of nation-building still could be described as an authoritarian type of Western modernity. Both modern institutional phenomena - the Estonian nation-state with its' practices of patronizing (from 1934), as well as civil society as agent and structure - still formed a relatively smooth dialogue.

From 1940, Estonian Western modern nation-state was replaced with Soviet state practices (1940-91) conceptualized as Soviet modernity. Soviet cultural policy aimed of creating a unified multinational Soviet nation and an homogeneous identity of the Soviet person within the institutionalized system of cultural production and total control of authorities. This did not tolerate any bottom-up initiatives of civil society or private entrepreneurs. In this pattern of Soviet modernity, we can follow the attempt 
to re-educate, inculcate the masses, and supress civil society in order to achieve total domination and control over the population.

According to the Soviet cultural canon, the national form was the required form for the Socialist content of Soviet culture. In terms of the Estonian (and Baltic) case, the Soviet cultural policy model was adapted to the institutions taking into account the previous experience of Western modernity which became the basis for conducting autonomous strategies that helped in escaping from Soviet hegemony.

The main difference in the nation-building programmes and state practices in cultural policies during the different states with different modernizing strategies could be pointed out as follows: during the Western variety of modernity (1860-1940), the core idea (as a basis and main aim for state cultural policy) of Estonian nation-building, was cultural emancipation, which was not derived merely from a top-down fictional political ideology of the state, as happened during Soviet modernity (1940-91), but was based on the historical national awakening of colonized ethnic group which expressed the will of the majority of the population to improve the status and position of Estonians up to and including national self-determination. During the Western modern state practices (1918-40) cultural policy was developed in cooperation between the state and civil society in Estonia.

However, it appears that civilizing aims, the national identity-building programme in the cultural canon and institutionalization were the driving forces and the historical cornerstones during all political systems and historical eras considered, as well as some of the basic aims in Estonian cultural policy. These features are typical of any modern nation-state's cultural policy, as they are related to identity and memory politics and used for the political representation in order to legitimate of the state as structure with its apparatus and political authority.

Answering the question on - how was Soviet cultural policy implemented in Estonia 194091, I have used the concept of Soviet state practices as a specific type of coercive modernity. In general, Soviet state practices were coercive and violent as Gerlach and Werth (2009), Mer- telsmann (2012), Naimark (2010), Keep (1995), Fitzpatrick (1999) et al explain: class struggle, oppression of the "enemies" of the Soviet state, (kulaks, priests, bourgeois specialists), attempts to achieve total control over the population, nationalization of private property, strict censorship, political agitation, the provision a set of canonized cultural norms were some of the key elements of sovietization. Soviet state practices did change over time, however, the main structures of the state model of the USSR established in the 1930s persisted until its collapse in 1991.

Soviet modernist cultural policy can be viewed as civilizing and enlightening via the Communist project of Soviet nation-building. Within this, the attempt to re-educate the masses, supressing civil society to achieve total institutionalized domination and control over the population - even in leisure - is evident. A range of party officials, administrative professionals and cultural workers prepared established norms and routines within a specific cultural education system for the rest of the population to follow. Through the creation of a cultural canon, Soviet leaders sought to provide a set of shared values and a common heritage of Soviet mass culture to form a common way of life - a monolithic Soviet society. The final aim of the Soviet cultural canon and cultural policy was to transform people's behaviour through a wide range of norms and practices, and to create a new social order, a Soviet society with its own mass-culture and a Soviet person - a mass-man in the Arendtian sense, in an atomized society.

The greatest change in Estonian society was the suppression of the bottom-up initiative and people's free time self-expression was replaced by guided and coordinated cultural practices. The entrepreneurial spirit and activities of civil society were prohibited and replaced by patronizing state financing and state interference in culture. However, subordinating civil society and critical reflection in society had crucial results for the Soviet empire. The conflict between civil society and state in the sense of agent-structure phenomena could be seen, where the totalitarian state lost or was left without the considerable amount of creativity civil society can offer. 
At the same time, the dialectics and ambivalent aspects of Soviet cultural policy and cultural welfare, within a broader access to culture, created the specific conditions for a homogeneous identity and promoted national resistance. With homogeneous cultural practices and institutionalized support for the nationalist form of culture, the Socialist state promoted ethnic particularism which was the precipitating power behind the Singing Revolution in Estonia (and other Baltic states). Thus, the Soviet cultural canon and cultural policy model dialectically worked against its aims.

Speaking about the roles of community houses during different political systems, it appeared that community houses played a vital part in the Estonian national awakening in the nineteenth and early twentieth centuries, as well as in the inclusion of the rural population in the cultural and national developments of the country during the interwar period of the Estonian republic (1918-40). The Estonian nation-state coordinated and supported the initiatives of civil society, but also standardized the functions and harmonized the architecture of these buildings. We can follow the democratic and liberal state interference and cooperation between the state and civil society. By 1938, more than 400 cultural centres belonged to the state network of community houses all over Estonia. Community houses operated as local institutions of Estonian cultural policy, being also the expression of the socio-economic and cultural vitality of Estonia's rural regions.

The sovietization process (1940-91) in respect of community houses meant the importation of the Soviet cultural canon (norms, values) and cultural policy model. The new official role for the community house was to be a political training centre for the local community. Censorship, a mandatory repertoire and guidelines were implemented for cultural activities. Songs, dances, orchestras, plays and party evenings were controlled by inspectors. Community houses were sovietized and became cultural policy tools in the hands of the authorities (that being the Communist Party), creating a new social order by the spreading of the Soviet cultural canon and socialist ideology. After World
War II, new buildings for cultural centres (in the monumental Stalinist style of architecture) were constructed by the Soviet authorities in Estonia and by 1950 there were 651 clubs and cultural centres.

However, due to the dialectics of Soviet cultural policy and the ambivalent nature of the community houses as party places, conceptualized here as Bakhtin's public square, these institutions also were arenas for the hidden resistance of Estonians against the oppressive regime. This kind of democratic ambivalence was a significant feature of the community houses during several political systems since the first of these houses were founded in 1887.

Through time, Stalinist political propaganda was gradually balanced by the state-financed homogeneous and standardized leisure activities of the people. As it appeared from the archival documents and reports of the Folk Art House in the 1960s and later, the general atmosphere in cultural work and education became more liberal and politically less suppressive.

In the documents, the questions of raising the quality of amateur arts, the promotion of folk arts and tradition of the Song Festival increasingly appeared. The Soviet cultural education system, courses, seminars for cultural work specialists (choreographers, conductors, amateur theatre directors, teachers of visual arts and handicraft) dealt more with the improvement of artistic skills of specialists working in the community houses.

Widely accessible, publicly-funded cultural leisure, folk and amateur art and homogeneous mass culture accounted for a substantial part of the Soviet cultural welfare of the closed society and state. At the same time as traditional cultural practices as the official canon of Soviet cultural policy was mediated, national resistance was promoted in the community houses. The strength (the mass mobilization) of the Estonian Singing Revolution came from this basis of indoctrinated, homogeneous cultural practices and the dialectics of Soviet cultural policy.

During the transition period (1991-95), a post-totalitarian lack of paradigm could also be observed in the community houses, while, simultaneously, the political, economic and of- 
ficial rhetoric on national identity changed in Estonia. Since then, community houses have lost their national importance and central government budget. Although state support for cultural institutions continued and community houses have been supported by local governments, in several cases the form of ownership of community houses has also been changed. (Kulbok-Lattik, Rüütel 2012) ${ }^{5}$ During the first transitional decade, some decline in the prestige of community houses due to their previous role as centres of Soviet political education was also felt. In addition, the transformation from a fully-financed system to a market economy resulted in some inability to adapt by the cultural workers, who also lacked ideological guidance that they could relate to, either for or against.

By now, liberal capitalism as prevailing political discourse has clearly expressed its rules and rhetoric during the twenty-plus years of the newly-independent Estonia. It has included statements like 'there is no such thing as a free lunch!' or 'money doesn't grow on trees!', as used widely by politicians. Together with these slogans, the New Public Management ideology - with the keywords of the three E's (economic value, effectiveness and efficiency) as its main aspects - has modelled the general understanding of the state, economy and culture (Kulbok-Lattik and Čopič, forthcoming).

By now, cultural workers in community houses are trained to write applications for cultural projects and deal with fundraising and other cultural management techniques in order to act. However, even today, despite the changes in political discourse, community houses are fulfilling their original functions of being the place for public meetings where local communities can discuss important matters (public sphere) and party places, offering space for cultural practices as well as for the festivities of the local people (public square). According to the data of Estonian Folk Culture Centre, ${ }^{6}$ there are today 464 community houses or cultural centres. Also, politicians visit public gatherings in order to give speeches, to meet their voters and it could be claimed that community houses have been used for political representation by the authorities during all of the different politi- cal systems in Estonia. However, it has been the nature of (as well as one of the original roles of) community houses to contribute to the cultural formation of the local public sphere, as well as the political.

Finally, as this dissertation on the historical formation and development of Estonian cultural policy belongs to the field of historical sociology, I have tried to demonstrate how social structures are shaped by agents as well as complex historical socio-economic processes and how they affect society and individuals. I have analysed the politics of cultural policy within different political systems, and the study has revealed that top-down authoritarian or (pro) totalitarian cultural policies (1934-91) with prevailing enlightening, educating and civilizing ethos and wide access, have been the most enduring historical experience in the Estonian experience of multiple modernities. In accordance with this, homogeneous cultural practices with nationalist overtones, institutionalized, centralized administration and insufficient critical reflection, have been bearing feature of the politics of Estonian cultural policy. Therefore, Estonian society still lacks the viewpoint of critical self-reflective studies with historical and sociological consciousness. On the other hand, it appears that if critical reflection and civil initiatives (also of the market) are subject to political doctrines, society will lose a considerable source of innovation.

It has been shown that each political system creates a specific set of management and institutional tools for cultural production in society. Thus, state interference in culture with its' dynamics of institutional meaning-making, shapes the selective tradition of culture and Foucauldian 'rituals of truth' and has an extended impact on the social order or the structure of feelings in the society. Culture is affected by the state's cultural policy, which shapes education, memory work and cultural institutions, creates professions, provides jobs and therefore has a broad impact on the identity and life of the individual. This clearly shows that cultural policy is a considerably powerful political instrument and needs a strong critical approach. 


\section{Endnotes}

1. Community normally means when people have something in common, sharing a geographical area (typically a neighbourhood), or people being brought together by common interests, identities or some combination of these factors. Communities operate by distinguishing those who belong ('insiders') from those who do not ('outsiders'). (Crow 2007, 617-620) Community is an important dimension of social divisions as well as togetherness because inclusion in community relationships promises benefits (material resources or raised social status) that set members apart from others, see Putnam (2000) Bowling Alone.

2. A political system is defined as the set of formal legal institutions that constitute a 'government' or a 'state.' This is the definition adopted by many studies of the legal or constitutional arrangements of advanced political orders. More broadly defined, the term encompasses existing as well as prescribed forms of political behaviour, not only the legal organization of the state but also the reality of how the state functions. Still more broadly defined, the political system is seen as a set of 'processes of interaction' or as a subsystem of the social system interacting with other non-political subsystems, such as the economic system.

3. 'Rechtsstaat' is a widely used term for state where government is bound by the law in its dealings with the citizens, its power is in other words limited by the individual rights to the people. /.../ The opposite of the 'Rechtsstaat' is the 'Polizeisstaat' ('police state') or the 'Machtsstaat ('state based on might'), where the arbitrary will of the persons in power prevails and the rulers do not have to observe legal norms. Van Caenegem R.C. An Historical Introduction to Western Constitutional Law. Cambridge University Press, 2003, 15-16.

4. Wittrock, Björn (2000) Modernity: One, None, or Many? European Origins and Modernity as a Global Condition. In: Daedalus; Winter 2000; 129, 1; ProQuest Library, p. 31; Arnason, Johann (2000). Communism and Modernity. In Multiple Modernities. 2000, Daedalus, 129, 1. ProQuest Research Library p 61; Eisenstadt, Shmuel (2000). Multiple Modernities. In: Daedalus; Winter, 1 pp. 1-29.

5. After 1991, the network of community houses has been excluded from central state budget and it has real consequences - increasingly, the community houses are handed over to local NGOs which have in many cases privatises the house, but in some cases, therefore dispossessing the local community of its communal centre. (Kulbok-Lattik, Rüütel 2012)

6. http://www.rahvakultuur.ee/?s=108 